\title{
Pertumbuhan Cabai Merah (Capsicum annuum L.) pada Tanah Masam yang Diinokulasi Mikoriza Vesikula Arbuskula (MVA) Campuran dan Pupuk Fosfat
}

\author{
Maryam Jamilah $^{1)}$, Purnomowati $^{1)}$, Uki Dwiputranto ${ }^{1)}$ \\ ${ }^{1)}$ Fakultas Biologi Universitas Jenderal Soedirman \\ email : mila_meonk3@yahoo.com
}

\begin{abstract}
This research aimed to find out the interaction effect between mixed Vesicular Arbuscular Mycorrhiza (VAM) and phosphate fertilizer to the growth of red chili (C. annuum) in acid soil, and to fnd out the best combination of mixed VAM and phosphate fertilizer to the growth of red chili (C. annuum) in acid soil. This research used an experimental method with Completely Randomized Design (CRD) in a factorial pattern with two factors. The first factor was mixed VAM dosages consisted of four levels: $0 ; 10 ; 15 ; 20 \mathrm{~g} / \mathrm{plant}$ which contains $10^{7} \mathrm{spores} / \mathrm{g}$. The second factor was phosphate fertilizer dosages consisted of four levels: $0 ; 0,2 ; 0,4 ; 0,6 \mathrm{~g} / \mathrm{plant}$. Each combination treatment had three replication. The parameters were observed in the form of plant height, stem diameter, plant top dry weight, degree of VAM infection, and P content of plant tissue. Data obtained from the observation was analyzed with Analysis of Variance (ANOVA) at an error rate of $5 \%$ and $1 \%$, treatment that showed significant or very significant result, then followed with Honestly Significant Difference (HSD) test. The result showed that interaction between mixed Vesicular Arbuscular Mycorrhiza (VAM) and phosphate fertilizer did not increase the plant height, stem diameter, and plant top dry weight, but each factor increased the plant height, stem diameter, and plant top dry weight. VAM dosage inoculation of $20 \mathrm{~g} /$ plant without phosphate fertilizer is the most effective combination in increasing the degree of VAM infection.
\end{abstract}

Keywords: $\quad$ Red chili (Capsicum annuum L.), acid soil, Vesicular Arbuscular Mycorrhiza (VAM), phosphate fertilizer

\begin{abstract}
Abrtrak
Penelitian ini bertujuan untuk mengetahui pengaruh interaksi antara Mikoriza Vesikula Arbuskula (MVA) campuran dan pupuk fosfat terhadap pertumbuhan tanaman cabai merah ( $C$. annuum) di tanah masam serta mengetahui kombinasi dosis MVA campuran dan pupuk fosfat yang terbaik untuk pertumbuhan tanaman cabai merah di tanah masam. Metode yang digunakan adalah eksperimental dengan Rancangan Acak Lengkap (RAL) pola faktoial dengan dua faktor. Faktor pertama berupa dosis MVA campuran yang terdiri dari $0 ; 10 ; 15 ; 20$ $\mathrm{g} /$ tanaman dengan kerapatan spora $10^{7}$ spora/gram. Faktor kedua berupa dosis pupuk fosfat yang terdiri dari 0 ; 0,$2 ; 0,4 ; 0,6 \mathrm{~g} /$ tanaman. Setiap kombinasi perlakuan diulang sebanyak 3 kali. Parameter yang diamati meliputi pertumbuhan tanaman (tinggi tanaman, diameter batang, berat kering tanaman bagian atas), derajat infeksi MVA, dan kandungan $\mathrm{P}$ jaringan tanaman. Data yang diperoleh dianalisis menggunakan Analisis Ragam (ANOVA) pada tingkat kesalahan $5 \%$ dan $1 \%$, perlakuan yang berpengaruh signifikan atau sangat signifikan dilanjutkan dengan uji Beda Nyata Jujur (BNJ). Hasil penelitian menunjukkan interaksi MVA campuran dan pupuk P tidak dapat meningkatkan tinggi, diameter batang, dan berat kering bagian atas tanaman cabai, namun secara mandiri pemberian MVA campuran dan pupuk $P$ dapat meningkatkan tinggi, diameter batang, dan berat kering bagian atas tanaman cabai merah. Dosis MVA campuran sebanyak $20 \mathrm{~g} /$ tanaman tanpa pupuk $\mathrm{P}$ paling efektif dalam meningkatkan derajat infeksi MVA pada akar tanaman cabai merah.
\end{abstract}

Katakunci: Cabai merah (Capsicum annuum L.) tanah masam, Mikoriza Vesikula Arbuskula (MVA), pupuk fosfat

\section{Pendahuluan}

Cabai merah (Capsicum annuum L.) merupakan tanaman hortikultura yang banyak dimanfaatkan untuk kebutuhan pangan. Menurut Rukmana dan Oesman (2006), pemanfaatannya dalam industri menjadikan cabai sebagai komoditas bernilai ekonomi tinggi. Berdasarkan data Badan Pusat Statistik dan Direktorat Jenderal Hortikultura (2012), luas areal panen cabai merah di Indonesia pada tahun 2008 tercatat seluas 109.178 ha dan pada tahun 2012 meningkat menjadi
120.275 ha, 22.706 ha diantaranya terdapat di propinsi Jawa Tengah. Bertambahnya luas areal tersebut disebabkan kebutuhan cabai meningkat sejalan dengan bertambahnya jumlah penduduk dan berkembangnya industri yang menggunakan cabai sebagai bahan baku. Kebutuhan cabai yang tinggi tidak diimbangi dengan produksi cabai yang mencukupi, sehingga upaya untuk menutupi kebutuhan cabai dilakukan melalui perluasan lahan pertanian (ekstensifikasi). 
Tanah di Indonesia sebagian besar merupakan tanah dengan sifat kimia masam, sehingga usaha perluasan lahan penanaman cabai mengalami kendala karena rendahnya derajat kemasaman $(\mathrm{pH})$ tanah, yaitu berkisar 4,0-5,5, sedangkan $\mathrm{pH}$ yang sesuai untuk budidaya cabai berkisar 5,5-6,8 dengan $\mathrm{pH}$ optimum 6,0-6,5 (Prajnanta, 2008). Rendahnya $\mathrm{pH}$ menyebabkan defisiensi fosfat $(\mathrm{P})$. Ketersediaan $\mathrm{P}$ menurun di bawah $\mathrm{pH}$ 5,5 karena terfiksasi oleh $\mathrm{Al}$, Fe, hidroksida, dan liat, sedangkan di atas $\mathrm{pH}$ 7,0 P difiksasi oleh Ca dan Mg (Tisdale et al., 1985).

Upaya untuk mengatasi defisiensi $P$ pada tanah masam, dapat dilakukan dengan pengapuran maupun pemupukan dengan tujuan meningkatkan $\mathrm{pH}$ tanah.Upaya untuk mengatasi kesuburan tanah yang rendah seperti tanah masam dapat dilakukan dengan pemanfaatan cendawan Mikoriza Vesikula Arbuskula (MVA). Cendawan MVA dapat bersimbiosis dengan akar dan mempunyai peranan yang penting dalam pertumbuhan tanaman, antara lain meningkatkan serapan fosfat $(P)$ dan unsur hara lainnya, seperti $N, K$, $\mathrm{Zn}$, Co, S dan Mo, meningkatkan ketahanan terhadap kekeringan, dan memperbaiki agregat tanah (Sukarno, 2003).

Menurut Harley dan Smith (1983), pengaruh MVA dalam pertumbuhan tanaman dapat secara langsung maupun tidak langsung. Hifa dapat mengambil hara seperti $\mathrm{P}$, dan mentranslokasikannya ke tanaman inang, yang langsung meningkatkan perolehan hara tanaman. Inokulasi cendawan MVA diketahui dapat meningkatkan serapan hara $\mathrm{N}$ dan $\mathrm{P}$ pada tanaman kedelai, meningkatkan efisiensi penggunaan pupuk $P$ dan mengurangi pemberian kapur pada tanah masam, serta meningkatkan hasil tanaman kedelai, kacang tanah, kacang hijau, jagung, dan ubi jalar (Simanungkalit, 1999).

\section{Metode Penelitian}

Bahan-bahan yang digunakan dalam penelitian ini adalah biji cabai merah varietas lokal, inokulum MVA campuran dengan carrier zeolith yang berisi Acaulospora sp., Glomus sp., dan Gigaspora desipiens tanah masam yang diambil dari daerah Gunung Tugel, Purwokerto, pupuk urea, $\mathrm{KCl}, \mathrm{TSP}, \mathrm{KOH} 10 \%$, larutan tinta cuka $5 \%$, air, dan akuades.

Metode yang digunakan dalam penelitian ini adalah eksperimental dengan Rancangan Acak Lengkap (RAL) pola faktorial. Faktor yang diujikan terdiri dari 2 faktor, yaitu Inokulasi MVA campuran dengan 4 taraf dosis: M0 (Tanpa inokulasi MVA), M1 (inokulasi MVA $10 \mathrm{~g} /$ tanaman dengan kerapatan spora $10^{7 /} \mathrm{g}$ ), M2 (inokulasi MVA $15 \mathrm{~g} /$ tanaman dengan kerapatan spora $10^{7 /} \mathrm{g}$ ), dan M3 (inokulasi MVA $20 \mathrm{~g} /$ tanaman dengan kerapatan spora $10^{7 /} \mathrm{g}$ ).
Jenis cendawan MVA yang telah diketahui dapat bersimbiosis dengan cabai adalah Gigaspora margarita (Haryantini dan Santoso, 2001), dan Glomus agregatum (Rahayu et al.,2002). Berdasarkan hasil percobaan kompatibilitas oleh Purnomo (2008), G. margarita mempunyai kemampuan koloni terbaik pada cabai. Menurut Halis et al (2008), dari hasil penelitiannya menggunakan 2 jenis MVA (Glomus sp., Gigaspora sp.) dan 4 dosis MVA (0 g, $5 \mathrm{~g}, 10 \mathrm{~g}$, dan $15 \mathrm{~g})$ didapatkan bahwa pemberian jenis dan dosis MVA berpengaruh terhadap tinggi, biomassa akar dan kandungan $P$ tanaman cabai. Hasil penelitian Husin (1997) menunjukkan bahwa pemberian inokulum mikoriza sebanyak $10 \mathrm{~g}$ per tanaman dapat meningkatkan serapan hara $\mathrm{P}$ (fosfat) dan tinggi tanaman jagung pada keadaan cekaman kekeringan.

Berdasarkan penelitian Suwarna et al. (2006), dosis pupuk P optimal untuk cabai merah tanpa penambahan MVA adalah 100 $\mathrm{kg} / \mathrm{ha}(1,6 \mathrm{~g} /$ tanaman), hal ini sesuai dengan anjuran Setiadi (2008) bahwa penggunakan pupuk $\mathrm{P}$ dalam bentuk TSP untuk cabai merah yang ditanam di tanah berkisar $100 \mathrm{~kg} / \mathrm{ha}$ atau 1,6 g/tanaman/polibag. Menurut Zulaikha dan Gunawan (2006), penambahan pupuk P dapat menurunkan aktivitas MVA. Meskipun diketahui bahwa kombinasi pupuk $\mathrm{P}$ dan dosis mikoriza dapat memperbaiki pertumbuhan tanaman, namun konsentrasi $\mathrm{P}$ yang tinggi di akar dapat menghambat perkecambahan spora dan pertumbuhan hifa cendawan pembentuk MVA.

Tujuan penelitian ini untuk mengetahui pengaruh interaksi antara MVA campuran dan pupuk fosfat terhadap pertumbuhan tanaman cabai merah di tanah masam serta mengetahui kombinasi dosis MVA campuran pupuk fosfat yang terbaik untuk pertumbuhan tanaman cabai merah di tanah masam.

Faktor kedua yaitu pemberian pupuk fosfat TSP berupa bubuk dengan 4 taraf dosis: P0 (tanpa pupuk fosfat), P1 (pupuk fosfat 0,2 $\mathrm{g} /$ tanaman), P2 (pupuk fosfat 0,4 g/tanaman), P3 (pupuk fosfat 0,6 g/tanaman).Masingmasing perlakuan diulang sebanyak 3 kali sehingga terdapat 48 unit percobaan.

Parameter yang diamati meliputi pertumbuhan tanaman (tinggi tanaman, diameter batang, berat kering tanaman bagian atas), derajat infeksi MVA, dan kandungan $P$ jaringan tanaman.

\section{Cara kerja}

Tanah yang telah diayak menggunakan saringan dengan ukuran 12 mesh diisikan ke dalam polibag sebanyak $5 \mathrm{~kg} /$ polibag, kemudian disterilisasi pada temperatur $100^{\circ} \mathrm{C}$ 
selama 6 jam.Tanah diinokulasi dengan MVA campuran sesuai dengan taraf perlakuan (10, 15, dan $20 \mathrm{~g} /$ tanaman). Pupuk fosfat yang diberikan adalah pupuk TSP sesuai dengan taraf perlakuan $(0,2,0,4$, dan 0,6 g/tanaman).

Benih cabai ditanam langsung pada tanah yang telah disiapkan sebanyak 3 biji per polibag dengan kedalaman lubang tanam \pm 2 $\mathrm{cm}$. Inokulum MVA campuran diberikan $30 \mathrm{~cm}$ dibawah lubang tanam biji cabai merah. Pemeliharaan tanaman yang dilakukan meliputi penyiraman dan penyiangan. Penyiraman dilakukan secara rutin 1-2 kali sehari sesuai dengan kondisi medium tanam.

\section{Pengamatan}

Pengamatan Tinggi tanaman, diameter batang, dan berat kering tanaman bagian atas dilakukan pada hari ke-50 setelah tanam (hst) dengan metode Sitompul dan Guritno (1995).
Pengamatan infeksi MVA dilakukan pada akhir penelitian (50 hst) dengan menggunakan metode clearing dan staining (Phillips dan Hayman, 1970) sebagai berikut :

a. Tanaman dicabut dan diambil akarnya. Akar dicuci dengan air dan dipotong-potong dengan panjang $1 \mathrm{~cm}$.

b. Potongan akar tersebut dimasukkan ke dalam larutan $\mathrm{KOH} \mathrm{10 \% ,} \mathrm{dipanaskan}$ selama 5 menit dengan temperatur $90^{\circ} \mathrm{C}$ menggunakan hot plate

c. Larutan $\mathrm{KOH}$ dibuang, akar dibilas dengan akuades 3-4 kali hingga warnanya menjadi jernih.

d. Potongan akar direndam dalam larutan tinta-cuka 5\% selama 12 jam, kemudian direndam dalam larutan akuades yang diberi beberapa tetes cuka.

e. Akar diamati dibawah mikroskop. Derajat infeksi MVA dihitung berdasarkan metode Giovannetti dan Mosse (1980):

$$
\text { Derajat Infeksi MVA }=\frac{\text { Eakar yang terinfeksi }}{\sum \text { akar yang diamati }} \times 100 \%
$$

\section{Hasil dan Pembahasan}

Berdasarkan hasil pengamatan, tinggi tanaman cabai merah berkisar antara 7,30$35,30 \mathrm{~cm}$. Rata-rata tinggi tanaman yang tertinggi terdapat pada perlakuan M3P1 yaitu $29,40 \mathrm{~cm}$, sedangkan rata-rata terendah terdapat pada kontrol (MOP0) yaitu 8,03 cm. Hasil Analisis Ragam pada tingkat kesalahan $5 \%$ dan $1 \%$ menunjukkan tidak adanya interaksi antara pemberian berbagai dosis MVA dengan pupuk fosfat dalam meningkatkan tinggi tanaman cabai yang ditanam di tanah masam. Sedangkan masingmasing faktor yang dicobakan menunjukkan pengaruh yang sangat signifikan pada tingkat kesalahan $1 \%$ terhadap tinggi tanaman cabai.

Tabel 1. Uji Beda Nyata Jujur (BNJ) pengaruh inokulasi MVA campuran terhadap tinggi tanaman cabai merah yang ditanam di tanah masam.

\begin{tabular}{cc}
\hline Perlakuan Pemberian MVA Campuran & Rata-rata Tinggi Tanaman \\
\hline M0 & $13,20^{\mathrm{a}}$ \\
M1 & $15,03^{\mathrm{a}}$ \\
M2 & $18,91^{\mathrm{ab}}$ \\
M3 & $21,85^{\mathrm{b}}$ \\
\hline
\end{tabular}

Keterangan : angka yang diikuti huruf yang sama tidak berbeda signifikan pada tingkat kesalahan $1 \%$

Hasil uji BNJ pengaruh inokulasi MVA campuran terhadap tinggi tanaman cabai merah yang dapat dilihat pada Tabel 1 menunjukkan bahwa semua perlakuan tidak berbeda signifikan dengan kontrol (M0) kecuali perlakuan M3 (20 g/tanaman). Pada perlakuan M3 yaitu sebesar $20 \mathrm{~g} /$ tanaman dicapai ratarata tertinggi untuk parameter tinggi tanaman dengan rata-rata 21,85 cm. Perlakuan M3 tidak berbeda signifikan dengan M2 (15 g/tanaman), dengan demikian dosis MVA $20 \mathrm{~g} /$ tanaman merupakan dosis MVA campuran yang paling efektif dalam meningkatkan tinggi tanaman cabai. Derajat infeksi yang tertinggi pada akar tanaman cabai pun dicapai pada perlakuan M3P0 (20 g MVA/tanaman tanpa pupuk P) yang dapat dilihat pada Tabel 7, menurut Gunawan (1993), tingginya derajat infeksi MVA pada perakaran tanaman dapat meningkatkan penyerapan unsur hara makro dan mikro terutama unsur $P$ yang sangat penting bagi pertumbuhan tanaman karena $\mathrm{P}$ berperan dalam pembentukan fosfolipid pada membran sel tanaman sehingga berpengaruh dalam pertambahan tinggi tanaman. Charisma (2012) mengemukakan bahwa MVA diketahui dapat menaikkan luas permukaan penyerapan pada sistem perakaran. Sehingga dapat meningkatkan kesuburan pada tanah dengan kandungan hara yang rendah.

Menurut Halis et al. (2008), berdasarkan hasil penelitiannya menggunakan 2 jenis MVA 
(Glomus sp., dan Gigaspora sp.), 4 dosis MVA $(0 \mathrm{~g}, 5 \mathrm{~g}, 10 \mathrm{~g}$, dan $15 \mathrm{~g})$ didapatkan bahwa pemberian jenis dan dosis MVA berpengaruh terhadap tinggi, biomassa akar dan kandungan $\mathrm{P}$ tanaman cabai. Pemberian Gigaspora sp. dengan dosis $15 \mathrm{~g}$ pada tanaman cabai memberikan hasil paling baik terhadap tinggi tanaman yaitu dengan rata-rata sebesar 21,73 $\mathrm{cm}$.

Tabel 2. Uji Beda Nyata Jujur (BNJ) pengaruh pemberian pupuk fosfat terhadap tinggi tanaman cabai merah yang ditanam di tanah masam.

\begin{tabular}{cc}
\hline Perlakuan Pemberian Pupuk Fosfat & Rataan Tinggi Tanaman \\
\hline P0 & $9,13^{\mathrm{a}}$ \\
P3 & $18,94^{\mathrm{b}}$ \\
P1 & $19,81^{\mathrm{b}}$ \\
P2 & $21,10^{\mathrm{b}}$ \\
\hline Keterangan : angka yang dikuti huruf yang sama tidak berbeda signifikan pada tingkat kesalahan $1 \%$
\end{tabular}

Keterangan : angka yang diikuti huruf yang sama tidak berbeda signifikan pada tingkat kesalahan $1 \%$

Hasil uji BNJ pengaruh pemberian pupuk fosfat (TSP) terhadap tinggi tanaman cabai merah yang dapat dilihat pada Tabel 2 menunjukkan bahwa semua perlakuan berbeda signifikan dengan kontrol (M0). Pada perlakuan P2 yaitu pemberian pupuk $P$ sebesar 0,4 g/tanaman dicapai rata-rata tertinggi untuk parameter tinggi tanaman dengan rata-rata $21,10 \mathrm{~cm}$, berbeda signifikan dengan kontrol (P0) namun tidak ada perbedaan signifikan dengan perlakuan P1 (0,2 pupuk $\mathrm{P} /$ tanaman) dan $\mathrm{P} 3$ (0,6 pupuk $\mathrm{P} /$ tanaman). Dengan demikian, dosis pupuk $\mathrm{P}$ sebesar 0,2 g/tanaman (P1) merupakan dosis yang paling efektif dalam meningkatkan tinggi tanaman cabai.

Menurut Haryantini dan Santoso (2001), unsur $\mathrm{P}$ memegang peranan penting dalam penyusunan berbagai elemen penting dalam tanaman seperti asam nukleat, juga sebagai penyimpan dan penyedia energi yang dibutuhkan dalam proses metabolisme sel tanaman. Unsur $\mathrm{P}$ berpengaruh terhadap perluasan permukaan daun sehingga laju fotosintesis tanaman dapat meningkat, dengan meningkatnya laju fotosintesis, maka pertumbuhan tinggi tanaman juga meningkat.

Hasil Analisis Ragam pada tingkat kesalahan $5 \%$ dan $1 \%$ menunjukkan tidak adanya interaksi antara pemberian berbagai dosis MVA dengan pupuk fosfat dalam meningkatkan diameter batang tanaman cabai merah yang ditanam di tanah masam. Masingmasing faktor yang dicobakan menunjukkan pengaruh yang sangat signifikan pada tingkat kesalahan $1 \%$ terhadap diameter batang tanaman cabai. Perlakuan pada masingmasing faktor diuji lanjut untuk membandingkan rata-rata setiap perlakuan. Hasil uji lanjut dengan uji Beda Nyata Jujur (BNJ) disajikan pada Tabel 3 dan Tabel 4.

Tabel 3. Uji Beda Nyata Jujur (BNJ) pengaruh inokulasi MVA campuran terhadap diameter batang tanaman cabai merah yang ditanam di tanah masam.

\begin{tabular}{cc}
\hline Perlakuan Pemberian MVA Campuran & Rata-rata Diameter Batang Tanaman \\
\hline M0 & $1,445^{\mathrm{a}}$ \\
M1 & $1,545^{\mathrm{a}}$ \\
M2 & $1,820^{\mathrm{ab}}$ \\
M3 & $2,137^{\mathrm{b}}$
\end{tabular}

Keterangan : angka yang diikuti huruf yang sama tidak berbeda signifikan pada tingkat kesalahan $1 \%$

Hasil uji BNJ pengaruh inokulasi MVA campuran terhadap diameter batang tanaman cabai merah yang dapat dilihat pada Tabel 3 menunjukkan bahwa perlakuan M1 (10 g MVA/tanaman), dan M2 (15 g MVA/tanaman) tidak memberikan perbedaan yang signifikan jika dibandingkan dengan kontrol (M0), sedangkan perlakuan M3 (20 g MVA/tanaman) menunjukkan perbedaan yang signifikan dibandingkan dengan kontrol. Pada perlakuan M3 yaitu sebesar $20 \mathrm{~g} /$ tanaman dicapai ratarata tertinggi untuk parameter diameter batang tanaman dengan rata-rata sebesar 2,137 mm. Perlakuan M3 menunjukan perbedaan yang signifikan dengan kontrol (M0) dan M1 (10 g/tanaman), namun tidak signifikan jika dibandingkan dengan M2 (15 g/tanaman). Dengan demikian, dosis MVA $20 \mathrm{~g} /$ tanaman (M3) merupakan dosis MVA campuran yang paling efektif dalam meningkatkan diameter batang tanaman cabai. Menurut Agustin et al. (2010), pemberian MVA diketahui dapat meningkatkan kemampuan dan efisiensi 
tanaman dalam menyerap hara $\mathrm{P}$ untuk

menunjang pertumbuhan dan hasil tanaman.

Tabel 4. Uji Beda Nyata Jujur (BNJ) pengaruh pemberian pupuk fosfat terhadap diameter batang tanaman cabai merah yang ditanam di tanah masam.

\begin{tabular}{cc}
\hline Perlakuan Pemberian Pupuk Fosfat & Rataan Diameter Batang Tanaman \\
\hline P0 & $1,15^{\mathrm{a}}$ \\
P3 & $1,83^{\mathrm{b}}$ \\
P1 & $1,91^{\mathrm{b}}$ \\
P2 & $2,05^{\mathrm{b}}$ \\
\hline Keterangan : angka yang diikuti huruf yang sama tidak berbeda signifikan pada tingkat kesalahan $1 \%$
\end{tabular}

Hasil uji BNJ pengaruh pemberian pupuk fosfat terhadap diameter batang tanaman cabai merah yang dapat dilihat pada Tabel 4 menunjukkan bahwa semua perlakuan berbeda signifikan dengan kontrol (P0). Pada perlakuan P2 yaitu pemberian pupuk $P$ sebesar 0,4 g/tanaman dicapai rata-rata tertinggi untuk parameter diameter batang tanaman dengan rata-rata diameter batang 2,05 mm. Perlakuan P2 berbeda signifikan dengan kontrol (P0), namun tidak ada perbedaan signifikan dengan perlakuan $\mathrm{P} 1$ (0,2 g/tanaman) dan P3 (0,6 g/tanaman). Dengan demikian, dosis pupuk $P$ sebesar 0,2 $\mathrm{g} /$ tanaman (P1) merupakan dosis yang paling efektif dalam meningkatkan diameter batang tanaman cabai.

Menurut Charisma (2012), MVA dapat memproduksi asam-asam organik dan enzim fosfatase yang dapat membebaskan unsur $P$ terikat yang berada di zona labil sehingga dapat diserap dan dimanfaatkan oleh akar tanaman. Mikoriza juga dapat menaikkan luas permukaan penyerapan pada sistem perakaran. Sehingga dapat meningkatkan kesuburan pada tanah dengan kandungan hara yang rendah. Menurut Haryantini dan Santoso (2001), fosfat memiliki peranan penting dalam berbagai proses metabolisme di dalam tanaman serta dalam proses pembelahan dan pembesaran sel. Ketersediaan fosfat yang cukup dapat mempercepat proses-proses tersebut yang merupakan proses dalam pertumbuhan tanaman seperti tinggi tanaman maupun diameter batang tanaman.

Hasil Analisis Ragam pada tingkat kesalahan 5\% dan $1 \%$ menunjukkan tidak adanya interaksi antara pemberian berbagai dosis MVA dengan pupuk fosfat dalam meningkatkan berat kering bagian atas tanaman cabai merah yang ditanam di tanah masam, sedangkan masing-masing faktor yang dicobakan menunjukkan pengaruh yang sangat signifikan pada tingkat kesalahan $1 \%$ terhadap berat kering bagian atas tanaman cabai. Perlakuan pada masing-masing faktor diuji lanjut untuk membandingkan rata-rata setiap perlakuan. Hasil uji lanjut dengan Beda Nyata Jujur (BNJ) disajikan pada Tabel 5 dan Tabel 6.

Tabel 5. Uji Beda Nyata Jujur (BNJ) pengaruh inokulasi MVA campuran terhadap berat kering bagian atas tanaman cabai merah di tanah masam.

\begin{tabular}{cc}
\hline Perlakuan Pemberian MVA Campuran & $\begin{array}{c}\text { Rataan Berat Kering Bagian Atas } \\
\text { Tanaman }\end{array}$ \\
\hline M0 & $0,0645^{\mathrm{a}}$ \\
M1 & $0,0897^{\mathrm{a}}$ \\
M2 & $0,2308^{\mathrm{a}}$ \\
Keterangan : angka yang diikuti huruf yang sama tidak berbeda signifikan pada tingkat kesalahan $1 \%$
\end{tabular}

Hasil uji BNJ pengaruh inokulasi MVA campuran terhadap berat kering bagian atas tanaman cabai merah yang dapat dilihat pada Tabel 5 menunjukkan bahwa semua perlakuan tidak berbeda dengan kontrol (M0). Pada perlakuan M3 yaitu sebesar $20 \mathrm{~g}$ MVA/tanaman dicapai rata-rata tertinggi untuk parameter berat kering tanaman bagian atas dengan rata-rata sebesar 0,2677 g. Meskipun memberikan rata-rata tertinggi terhadap berat kering tanaman bagian atas, namun berdasarkan hasil Uji BNJ, dapat dilihat bahwa perlakuan M3 (20 g MVA/tanaman) tidak memperlihatkan hasil yang berbeda signifikan bila dibandingkan dengan kontrol M0, M1 (10 g MVA/tanaman) dan M2 (15 g MVA/tanaman). Dengan demikian, dapat disimpulkan bahwa tanpa inokulasi MVA maupun dengan 
penambahan MVA tidak berpengaruh secara signifikan dalam meningkatkan berat kering tanaman bagian atas.

Tabel 6. Uji Beda Nyata Jujur (BNJ) pengaruh pemberian pupuk fosfat terhadap berat kering bagian atas tanaman cabai merah yang ditanam di tanah masam.

\begin{tabular}{cc}
\hline Perlakuan Pemberian Pupuk Fosfat & Rataan Berat Kering Bagian Atas Tanaman \\
\hline P0 & $0,0170^{\mathrm{a}}$ \\
P3 & $0,1583^{\mathrm{ab}}$ \\
P1 & $0,1913^{\mathrm{ab}}$ \\
P2 & $0,2862^{\mathrm{b}}$ \\
\hline Keterangan : angka yang diikuti huruf yang sama tidak berbeda signifikan pada tingkat kesalahan $1 \%$
\end{tabular}

Hasil uji BNJ pengaruh pemberian pupuk fosfat terhadap berat kering bagian atas tanaman cabai merah yang dapat dilihat pada Tabel 6 menunjukkan bahwa semua perlakuan kecuali P2 $(0,4 \mathrm{~g}$ pupuk $\mathrm{P} /$ tanaman) tidak berbeda signifikan dengan kontrol (P0). Pada perlakuan $\mathrm{P} 2$ yaitu sebesar 0,4 g/tanaman dicapai rata-rata tertinggi untuk parameter berat kering tanaman bagian atas dengan ratarata $0,2862 \mathrm{~g}$. Perlakuan $\mathrm{P} 2$ tidak berbeda signifikan dengan perlakuan P1 $(0,2$ $\mathrm{g} /$ tanaman) dan P3 (0,6 g/tanaman). Dengan demikian, dosis pupuk $P$ sebesar 0,4 $\mathrm{g} /$ tanaman (P2) merupakan dosis yang paling efektif dalam meningkatkan berat kering bagian atas tanaman cabai.

Fosfat memiliki peranan penting dalam berbagai proses metabolisme di dalam tanaman serta dalam proses pembelahan dan pembesaran sel yang menunjang pertumbuhan tanaman. Fosfat juga berpengaruh dalam memperluas permukaan daun sehingga fotosintesis akan meningkat (Haryantini dan Santoso, 2001). Selain fosfat, kolonisasi MVA juga dapat meningkatkan akumulasi berat kering tanaman dan luas daun dibandingkan dengan tanaman yang tidak dikolonisasi MVA (Latef, 2011).

Pemberian mikoriza diketahui dapat meningkatkan kemampuan dan efisiensi tanaman dalam menyerap hara $P$ untuk menunjang pertumbuhan dan hasil tanaman (Agustin et al., 2010). Hifa eksternal cendawan MVA dapat membantu dalam penyerapan air dan unsur-unsur hara yang dibutuhkan dalam proses metabolisme di dalam tubuh tanaman sehingga dapat memacu pertumbuhan tanaman (Niswati et al., 1996).

Hasil Analisis Ragam pada tingkat kesalahan $5 \%$ dan $1 \%$ menunjukkan adanya interaksi antara pemberian berbagai dosis MVA campuran dengan pupuk fosfat yang berpengaruh sangat signifikan terhadap derajat infeksi MVA pada akar tanaman cabai merah yang ditanam di tanah masam. Masingmasing faktor yang dicobakan juga menunjukkan pengaruh yang sangat signifikan pada tingkat kesalahan $1 \%$ terhadap derajat infeksi MVA pada akar tanaman cabai. Pengaruh inokulasi MVA campuran dan pupuk fosfat terhadap derajat infeksi MVA diuji lanjut untuk membandingkan rata-rata setiap perlakuan. Hasil uji lanjut dengan Beda Nyata Jujur (BNJ) disajikan pada Tabel 7.

Hasil uji BNJ pengaruh inokulasi MVA campuran dan pupuk fosfat terhadap derajat infeksi MVA pada akar tanaman cabai merah yang dapat dilihat pada Tabel 7 menunjukkan bahwa semua perlakuan berbeda signifikan dengan kontrol (MOPO), kecuali perlakuan M0P1 (tanpa MVA dan 0,2 g pupuk P/tanaman), M0P2 (tanpa MVA dan 0,4 g pupuk P/tanaman), dan MOP3 (tanpa MVA dan $0,6 \mathrm{~g}$ pupuk $\mathrm{P} /$ tanaman). Hal ini disebabkan karena tidak adanya inokulum yang diberikan, sehingga tidak terjadi infeksi pada akar tanaman cabai merah. Kombinasi dosis MVA campuran dan pupuk fosfat yang paling efektif dalam menginfeksi akar tanaman cabai merah yang ditanam di tanah masam adalah pada perlakuan M3P0 $(20 \quad \mathrm{~g} \quad$ MVA campuran/tanaman dan tanpa pupuk $P$ ) dengan rata-rata 61,49. Perlakuan M3P0 tidak berbeda signifikan dengan perlakuan M3P1 (20 g MVA campuran/tanaman, dan 0,2 g pupuk P/tanaman), M3P2 (20 g MVA campuran/tanaman, dan 0,4 $\mathrm{g}$ pupuk P/tanaman), M2P2 (15 g MVA campuran/tanaman, dan 0,4 g pupuk $\mathrm{P} /$ tanaman), dan M2P1 (15 g MVA campuran/tanaman, dan 0,2 g pupuk $\mathrm{P} /$ tanaman). Dengan demikian, kombinasi dosis $20 \mathrm{~g}$ MVA campuran/tanaman dan tanpa pupuk $\mathrm{P}$ (M3P0) merupakan yang paling efektif dalam meningkatkan derajat infeksi MVA pada akar tanaman cabai merah.

Derajat infeksi MVA pada perakaran cabai merah yang di tanam di tanah masam dalam penelitian ini tergolong cukup tinggi. Derajat infeksi MVA tergolong tinggi jika derajat infeksinya lebih dari 30\% (O'Connor et al., 2001). Semakin tinggi dosis MVA yang 
digunakan, maka akan semakin tinggi pula derajat infeksi MVA pada perakaran tanaman. Derajat infeksi MVA tertinggi terdapat pada perlakuan M3P0 (20 g MVA campuran / tanaman dan tanpa pupuk P). Menurut Probosari (2011), tanaman cenderung mudah terinfeksi MVA bila berada pada tanah yang miskin unsur hara. Permeabilitas membran sel akar tanaman di lingkungan tanah masam seperti ultisol akan meningkatkan terjadinya perombakan hasil metabolisme sperti gula reduksi dan asam amino yang dapat memacu pertumbuhan MVA, selain itu tanah masam seperti tanah ultisol juga memungkinkan terjadinya infeksi oleh MVA karena ketersediaan haranya, terutama unsur $P$ yang rendah.
Hasil Analisis Ragam pada tingkat kesalahan $5 \%$ dan $1 \%$ menunjukkan adanya interaksi antara MVA campuran dengan pupuk fosfat yang berpengaruh sangat signifikan terhadap kandungan $P$ jaringan tanaman cabai merah yang ditanam di tanah masam. Pemberian pupuk $P$ juga menunjukkan pengaruh yang sangat signifikan pada tingkat kesalahan 1\%, sedangkan inokulasi MVA campuran menunjukkan pengaruh yang tidak signifikan terhadap kandungan $P$ jaringan tanaman cabai. Pengaruh interaksi kedua faktor diuji lanjut untuk membandingkan ratarata setiap perlakuan. Hasil uji lanjut dengan uji Beda Nyata Jujur (BNJ) disajikan pada Tabel 8.

Tabel 7. Uji Beda Nyata Jujur (BNJ) pengaruh inokulasi MVA campuran dan pupuk fosfat terhadap derajat infeksi MVA pada akar tanaman cabai merah yang ditanam di tanah masam.

\begin{tabular}{cc}
\hline $\begin{array}{c}\text { Perlakuan Pemberian MVA Campuran dan } \\
\text { Pupuk Fosfat }\end{array}$ & $\begin{array}{c}\text { Rataan Derajat Infeksi MVA pada Akar } \\
\text { Tanaman }\end{array}$ \\
\hline M0P0 & $4,05^{\mathrm{a}}$ \\
M0P1 & $4,05^{\mathrm{a}}$ \\
M0P2 & $4,05^{\mathrm{a}}$ \\
M0P3 & $4,05^{\mathrm{a}}$ \\
M1P2 & $35,55^{\mathrm{b}}$ \\
M1P3 & $38,54^{\mathrm{bc}}$ \\
M1P1 & $41,44^{\mathrm{bcd}}$ \\
M1P0 & $43,37^{\mathrm{bcde}}$ \\
M2P0 & $46,24^{\text {cdef }}$ \\
M3P3 & $49,14^{\text {defg }}$ \\
M2P3 & $51,08^{\text {efgh }}$ \\
M2P1 & $54,06^{\text {fghi }}$ \\
M2P2 & $56,08^{\text {ghi }}$ \\
M3P2 & $58,18^{\text {hi }}$ \\
M3P1 & $59,33^{\mathrm{i}}$ \\
M3P0 & $61,49^{\mathrm{i}}$ \\
\hline
\end{tabular}

Keterangan : angka yang diikuti huruf yang sama tidak berbeda signifikan pada tingkat kesalahan $1 \%$

Hasil uji BNJ pengaruh inokulasi MVA campuran dan pupuk fosfat terhadap kandungan $\mathrm{P}$ jaringan tanaman cabai merah yang dapat dilihat pada Tabel 8 menunjukkan bahwa semua perlakuan tidak berbeda signifikan dengan kontrol (MOP0). Dengan demikian, tanpa inokulasi MVA dan pupuk $P$ pun sudah efektif dalam meningkatkan kandungan $\mathrm{P}$ jaringan tanaman cabai merah yang ditanam di tanah masam. Hasil penelitian menunjukkan adanya interaksi antara MVA campuran dengan pupuk fosfat yang berpengaruh terhadap kandungan $\mathrm{P}$ jaringan tanaman cabai merah yang ditanam di tanah masam meskipun semua perlakuan tidak menunjukkan perbedaan signifikan dengan kontrol pada uji BNJ.

Menurut Gunawan (1993), MVA mampu menghasilkan enzim fosfatase yang mampu mengkatalis hidrolis komplek fosfat tidak larut di dalam tanah menjadi bentuk fosfat larut yang tersedia bagi tanaman. Karena itulah, 
tanaman yang diinokulasi MVA akan dapat menyerap $P$ dari tanah dengan $P$ tersedia rendah seperti tanah masam dan dari pupuk yang diberikan sehingga penyerapan $P$ menjadi lebih besar dibanding tanaman yang tidak diinokulasi MVA. Cendawan MA memiliki struktur hifa yang menjalar keluar ke dalam tanah. Hifa meluas di dalam tanah, melampaui jauh jarak yang dapat dicapai oleh rambut akar. Ketika fosfat di sekitar rambut akar tidak tersedia, maka hifa membantu menyerap fosfat di bagian yang tidak dapat lagi dijangkau rambut akar (Simanungkalit, 1999)

Tabel 8. Uji Beda Nyata Jujur (BNJ) pengaruh inokulasi MVA campuran dan pupuk fosfat terhadap kandungan $\mathrm{P}$ jaringan tanaman cabai merah yang ditanam di tanah masam.

\begin{tabular}{cc}
\hline $\begin{array}{c}\text { Perlakuan Pemberian MVA Campuran dan } \\
\text { Pupuk Fosfat }\end{array}$ & $\begin{array}{c}\text { Rataan Kandungan P Jaringan } \\
\text { Tanaman }\end{array}$ \\
\hline M0P0 & $6,15^{\mathrm{ab}}$ \\
M0P2 & $4,75^{\mathrm{ab}}$ \\
M0P3 & $6,03^{\mathrm{ab}}$ \\
M1P0 & $5,74^{\mathrm{ab}}$ \\
M1P1 & $4,58^{\mathrm{ab}}$ \\
M1P2 & $4,00^{\mathrm{a}}$ \\
M1P3 & $6,32^{\mathrm{ab}}$ \\
M2P0 & $6,33^{\mathrm{ab}}$ \\
M2P1 & $4,12^{\mathrm{a}}$ \\
M2P2 & $5,91^{\mathrm{ab}}$ \\
M2P3 & $5,38^{\mathrm{ab}}$ \\
M3P0 & $5,75^{\mathrm{ab}}$ \\
M3P1 & $3,75^{\mathrm{a}}$ \\
M3P2 & $5,14^{\mathrm{ab}}$ \\
M3P3 & $4,93^{\mathrm{ab}}$ \\
\hline Keterangan : angka yang dikuti huruf yang sama tidak berbeda signifikan pada tingkat kesalahan $1 \%$
\end{tabular}

\section{Simpulan}

Berdasarkan hasil dan pembahasan, maka dapat disimpulkan bahwa pemberian kombinasi MVA campuran dan pupuk $P$ tidak dapat meningkatkan tinggi, diameter batang, dan berat kering bagian atas tanaman cabai, namun secara mandiri pemberian MVA campuran dan pupuk $P$ dapat meningkatkan

\section{Daftar Pustaka}

Agustin, W., S. Ilyas, S.W. Budi, I. Anas, F.C. Suwarno. 2010. Inokulasi Fungi Mikoriza Arbuskula (FMA) dan pemupukan $p$ untuk meningkatkan hasil dan mutu benih cabai (Capsicum annuum L.). J. Agron. Indonesia, 38 (3) : 218 -224.

Badan Pusat Statistik dan Direktorat Jenderal Hortikultura. 2012. Luas Panen Cabe tinggi, diameter batang, dan berat kering bagian atas tanaman cabai merah. Dosis MVA campuran sebanyak $20 \mathrm{~g} /$ tanaman tanpa pupuk $P$ paling efektif dalam meningkatkan derajat infeksi MVA pada akar tanaman cabai merah. 
tanam tanah kapur. LenteraBio, 1(3): 111-116.

Giovannetti, M., dan B. Mosse. 1980. An evaluation of technqiues for measurng VAM infection in roots. New Phytol. 84: 489-500.

Gunawan, A.W. 1993. Bahan pengajaran mikoriza arbuskula. Pusat Antar Universitas IImu Hayat IPB, Bogor.

Halis, P. Murni, dan A.B. Fitria. 2008. Pengaruh Jenis dan dosis cendawan mikoriza arbuskular terhadap pertumbuhan cabai (Capsicum annuum L.) pada tanah ultisol. Biospecies, 1 (2): $59-62$.

Harley, J.L., dan S.E. Smith. 1983. Mycorrhizal symbiosis. Academic Press, London.

Haryantini, B.A., M. Santoso. 2001. Pertumbuhan dan hasil cabai merah pada andisol yang diberi mikoriza, pupuk fosfat dan zat pengatur tumbuh. Biosain 1(3): 50-57.

Husin, E.F. 1997. Respon beberapa jenis tanaman terhadap mikoriza vesikula arbuskular dan pupuk fospat pada ultisol. Prosiding Pemanfaatan Cendawan Mikoriza untuk Meningkatkan Produksi Tanaman pada Lahan Marginal. Asosiasi Mikoriza IndonesiaUniversitas Jambi.

Latef, A.A.H.A. 2011. Influence of arbuscular mycorrhizal fungi and copper on growth, accumulation of osmolyte, mineral nutrition and antioxidant enzyme activity of pepper (Capsicum annuum L.). Mycorrhiza, 21:495-503.

Niswati, A., S.G. Nugoho, M. Halis, dan Suryadi. 1996. Pemanfaatan mikoriza vesikular arbuskular untuk mengatasi pertumbuhan jagung akibat cekaman kekeringan. Jurnal IImu Tanah, 2(3):2527.

O' Connor, J.P., S.E. Smith,. dan F.A Smith. 2001. Arbuscular mycorrhizal asssociations in the Southern Simpson Desert. Australian Journal of Botany, 49(4): 493 - 499.

Philips, J.M dan D.S. Hayman. 1970. Improved procedures for clearing roots and staining parasitic and vesicular arbuscular mycorrhizal fungi for rapid assessment of infection. Transact. British Mycolog. Soc, 55: 158 - 160.

Prajnanta, F. 2008. Agribisnis cabai hibrida. Penebar Swadaya, Bogor.

Probosari, R.M. 2011. Pertumbuhan tanaman kedelai (Glycine max (L.) Merr.) yang diinokulasi dengan campuran Mikoriza VA di tanah ultisol. Prosiding Seminar Biologi, 8(1): 487-492.

Purnomo, D.W. 2008. Keefektifan fungi mikoriza arbuskula dalam meningkatkan hasil dan adaptasi cabai (Capsicum annuum L.) pada tanah bercekaman aluminium. Tesis (tidak dipublikasikan). Sekolah Pascasarjana Institut Pertanian Bogor, Bogor.

Rahayu, A., Setyono, N. Rochman. 2002. Pengaruh mikoriza dan stres air terhadap respon tanaman cabai merah. Laporan Penelitian (tidak dipublikasikan). Fakultas Pertanian Unida, Bogor.

Rukmana, R., Y.Y. Oesman. 2006. Bertanam cabai dalam pot. Kanisius, Yogyakarta.

Setiadi. 2008. Bertanam cabai. Penebar Swadaya, Bogor.

Simanungkalit, R.D.M. 1999. Penelitian Pemanfaatan Cendawan Mikoriza Arbuskular pada Tanaman Pangan di Indonesia. Prosiding Seminar Nasional I. Bogor, 15-16 Nopember 1999.

Sitompul, S.M., dan B. Guritno. 1995. Analisis pertumbuhan tanaman. Gadjah Mada University Press, Yogyakarta.

Sukarno, N. 2003. Mikoriza dan peranannya. Jurusan Biologi FMIPA Institut Pertanian Bogor, Bogor.

Suwarna, A., M. Sigit, dan M. Santoso. 2006. Pertumbuhan dan Hasil Cabe Merah (Capsicum annum) pada Andisol yang Diberi Mikoriza, Pupuk Fosfor, dan Zat Pengatur Tumbuh

Tisdale, S.L., W.L. Nelson, J.D. Beaton. 1985. Soil fertility and fertilizer. $4^{\text {th }}$ Ed. Mac millan Publishing Company, New York.

Zulaikha, S., dan Gunawan. 2006. Serapan fosfat dan respon fisiologis tanaman cabai merah cultivar hot beauty terhadap mikoriza dan pupuk fosfat pada tanah ultisol. Bioscientiae, 3(2): 83-92. 